\title{
Sex ratio and morphological characteristics of Rufous Gnateaters, Conopophaga lineata (Aves, Passeriformes) in Atlantic forest fragments
}

\author{
Gisele P. M. Dantas ${ }^{1}$, Fabrício R. Santos² \& Miguel Ângelo Marini ${ }^{3}$
}

1. Instituto de Biociências, USP, Rua do Matão, 277, Cidade Universitária, 05508-090 São Paulo, SP, Brazil. (giselebio@yahoo.com.br) 2. Departamento de Biologia Geral, Instituto de Ciências Biológicas, UFMG, Caixa Postal 486, 31270-901 Belo Horizonte, MG, Brazil. 3. Departamento de Zoologia, Instituto de Ciências Biológicas, UnB, 70910-900 Brasília, DF, Brazil.

\begin{abstract}
Unequal sex ratios lead to the loss of genetic variability, decreasing the viability of populations in the long term. Anthropogenic activities often disturb the natural habitats and can cause alterations in sex ratio and morphological characteristics of several species. Forest fragmentation is a major conservation concern, so that understanding its effects in natural populations is essential. In this study, we evaluated the sex ratio and the morphological characteristics of Rufous Gnateaters (Conopophaga lineata (Wied, 1831)) in small and large forest fragments in Minas Gerais, Brazil. Birds $(\mathrm{n}=89)$ were sexed by plumage characteristics and molecular markers. The molecular analysis showed that plumage is not a totally reliable method for sexing Rufous Gnateaters. We observed that sex ratio did not differ between large and small forest fragments, but birds in small fragments had larger wings and tarsus Wing and tarsus changes may affect the movement ability of individuals within and among forest fragments. In conclusion, Rufous Gnateaters have been able to survive in both small and large Atlantic rain forest fragments without altering their sex ratio, but morphological changes can be prejudicial to their long term survival.
\end{abstract}

KEYWORDS. Forest fragmentation, sex ratio, Atlantic forest, Conopophagidae.

RESUMO. Razão sexual e características morfológicas do chupa-dente, Conopophaga lineata (Aves, Passeriformes) em fragmentos da Mata Atlântica. A razão sexual desigual pode levar à perda de variabilidade genética, diminuindo a viabilidade das populações em longo prazo. Atividades antrópicas causam alterações nos hábitats e podem causar mudanças na razão sexual e na morfologia de muitas espécies. A fragmentação florestal é uma grande preocupação em conservação e entender os seus efeitos em populações naturais é fundamental. Assim, neste estudo buscamos investigar a razão sexual e algumas características morfológicas do chupa-dente (Conopophaga lineata (Wied, 1831)) em fragmentos pequenos e grandes no Estado de Minas Gerais, Brasil. As aves (n = 89) foram sexadas através de características da plumagem e através de marcadores moleculares. Marcadores moleculares indicaram que a identificação por plumagem não é um método totalmente confiável para essa espécie. Observamos que a razão sexual não difere entre os fragmentos grandes e pequenos, mas os indivíduos dos fragmentos pequenos apresentaram asas e tarsos maiores. Modificações nas asas e tarsos podem causar alterações no deslocamento dos indivíduos dentro e entre os fragmentos. Portanto, os chupa-dentes têm sido capazes de sobreviver mesmo nos pequenos fragmentos de Mata Atlântica sem sofrer alterações na razão sexual. Porém, as diferenças morfológicas apresentadas podem ser prejudiciais para a sobrevivência da espécie a longo prazo.

PALAVRAS-CHAVE. Fragmentação florestal, razão sexual, Mata Atlântica, Conopophagidae.

Sex ratio is defined as the proportion of males to females in a population (PIANKA, 1999). This proportion is separated by life stage of the organisms, being characterized as primary sex ratio when in egg phase, secondary in nestling phase, tertiary in immature adults and quarternary in breeding adults (PIANKA, 1999).

Sex ratio is an important parameter to understand the life history of a population, being the result of several ecological, behavioral and evolutionary factors (SEGER $\&$ Stubblefield, 2002). Changes in sex ratio are usually associated with mating system, sex determination mechanisms (growth differences between the sexes), decreasing of population size and anthropogenic activities (Clutton-Brock, 1985; Frankham et al., 2002). Unequal sex ratios can lead to loss of genetic variability due to endogamy (PAXTON et al., 2002), decreasing the viability of the populations in the long term (DOHERTY \& Grubb, 2002), since genetic diversity is essential to species responses to environmental changes.

Natural selection benefits parents who invest similarly in sons and daughters (TRIVERS \& WILLARD, 1973). However, it is known that males and females show differences of energetic costs during development
(Clutton-Brock et al., 1985; Sheldon et al., 1998). This distinct energetic cost is a main factor that could influence the primary (egg phase) and secondary (nestling phase) sex ratios in dioecious organisms (PIANKA, 1999). In mammals and birds with sexual dimorphism, males grow faster than females, thus males need more nutrients to grow (Clutton-BRock et al., 1985). In this way the parents can selected the sex of the offspring depending on the environmental conditions. Under extreme conditions, females can feed one sex more than the other, preferably the sex with less energetic cost (COCKBURN et al., 2002). However, through evolutionary time species tend to balance the sex-ratio invested in the less abundant sex (rare sex) (TRIVERS \& WILLARD, 1973).

Forest fragmentation increases the amount of edge and thus increases light incidence in the core area, reduce humidity and modify habitat's physical structure (Soulé, 1986). These changes may further increase pressures from predation, competition, parasites and diseases, consequently reducing survival rate and reproductive fitness (BIERREGAARD et al., 1992; Rolstad, 1991). Fragmentation may also decrease food supplies due to changes in abundance and diversity of invertebrates in 
fragmented areas (BARbosa \& MARquet, 2002; KoIvUla \& Vermeulen, 2005). Fragmentation can also reduce the area available to forage and to breed, leading to smaller population sizes in fragmented regions (BIERREGAARD et al., 1992).

Other ways forest fragmentation can also modify morphological characteristics are through genetic (inbreeding) and environmental stress (pollutants, parasitism and low food availability) (SoULÉ, 1986; ANCIÃES \& MARINI, 2000). Modifications in morphological characteristics are directly under selection, since they are associated to survival in altered environments (LEARY \& AllendorfF, 1989). ANCIÃEs \& MARINI (2000), studying Passeriformes in the Atlantic rain forest, detected higher asymmetry in morphological traits in birds from smaller than from larger forest fragments.

The Brazilian Atlantic rain forest originally occupied an area of 1.1 million $\mathrm{km}^{2}$ and covered a large extension of the Brazilian coast. Nowadays, this biome is considered one of the world's most important conservation hotspot areas, due to its high levels of endemism and degradation, remaining only $5 \%$ of its original area (MYERs et al., 2000). Most of the remaining forests are located in regions of steep topography, where agriculture and cattle ranching are not economically viable.

Rufous Gnateaters, Conopophaga lineata (Wied, 1831), are small understory insectivorous birds that occur in tropical and temperate forests of South America (SIGRIST, 2005), from Paraguay and northeastern Argentina to northeastern Brazil (Sick, 1997). This is a common species in the Atlantic forest. However, despite its large distribution, few studies have been done to understand its biology and ecology (WILLIS et al., 1983; SicK, 1997). Its wide distribution along the Atlantic forest, and usually high abundance, along with the easiness they are captured in mist-nets, make this species a good model for studies concerning the effects of forest fragmentation in the Neotropics.

In this study, we evaluated sex ratio and morphological characteristics of $C$. lineata in Atlantic forest fragments in the State of Minas Gerais, Brazil. We specifically addressed a comparison of $C$. lineata quaternary sex ratio (adults phase) in small and large fragments, whether morphological characteristics of the birds have been affected by habitat fragmentation and whether fragmentation is affecting males and females differently, modifying their morphological characteristics.

\section{MATERIAL AND METHODS}

Conopophaga lineata specimens were captured with mist nets in ten fragments at five locations in the Atlantic rain forest of the State of Minas Gerais, Brazil, between August 2000 and November 2001. At each location, two fragments were sampled: a large one $(>1,000$ ha) and a small one (10-30 ha). Fragments were immersed in a matrix of monocultures or pastureland and always isolated at least $1 \mathrm{~km}$ from each other. Birds were captured from dawn to 17:00 h, with 20 mist nets per day and a mean sample effort of 640 mistnet hours/fragment. Captured birds received a metal band provided by CEMAVE/IBAMA.
Morphological characteristics (wing length, tarsus, nostril, tail and body mass) were taken with metal calipers and spring scales. Birds were sexed in the field by plumage, with males presenting a white post ocular tuft and females presenting a gray tuft. Blood samples were collected $(\sim 0.1$ $\mathrm{ml}$ ) from a tarsus vein, and kept in $70 \%$ alcohol at $4^{\circ} \mathrm{C}$ for posterior analysis in the laboratory. Genomic DNA was isolated from blood samples through standard phenol/ chloroform technique, precipitated with ethanol and resuspended in T.E. buffer (Tris-EDTA) (SAMBROOK et al., 2001). The extracted DNA was amplified by PCR according to the method described by GRIFFITHS et al. (1998) using primers P2 (5' -TCTGCAYCGCTAAATCCTTT-3') and P8 (5'-CTCCCAAGGATGAGRAAYTG-3'). The reaction was prepared to the final volume of $12.5 \mu \mathrm{l}$, containing 1X Buffer Taq polymerase (10mM Tris- $\mathrm{HCl}, \mathrm{pH} 8.3,50 \mathrm{mM}$ $\mathrm{KCl}), 1.5 \mathrm{mM} \mathrm{MgCl}_{2}, 2 \mathrm{mM}$ of each dNTPs, 8 pmol of each primer, $0.5 \mathrm{u}$ Taq polymerase and approximately $20 \mathrm{ng}$ of DNA. Polymerase Chain Reaction following profile: $94^{\circ} \mathrm{C}$ for $2 \mathrm{~min}$, followed by 35 cycles of $94^{\circ} \mathrm{C}$ for $30 \mathrm{~s}, 48^{\circ} \mathrm{C}$ for $45 \mathrm{~s}, 72^{\circ} \mathrm{C}$ for $45 \mathrm{~s}$, with final extension $72^{\circ} \mathrm{C}$ of $5 \mathrm{~min}$. The PCR products were separated by electrophoresis in $6 \%$ polyacrylamide gels and the bands were visualized by silver staining (SANTOS et al., 1996). Males were identified by the presence of a single band ( $380 \mathrm{bp}$ ) and females by the presence of two bands (380 and $400 \mathrm{bp}$ ).

Statistical analyses. Determination of sex by plumage coloration and molecular technique were compared with Mann-Whitney test. The sex ratio in each fragment was tested through $\chi^{2}$ test and the difference in sex ratio between large and small fragments was tested with Mann-Whitney. All morphologic characteristics are continuous variables with normal distributions (Kolmogorov-Smirnov test). Principal Component Analysis (PCA) was used to verify if the variables measured some structure (HAIR et al., 1995). This is an exploratory analysis which correlated all variables (fragment size, sex, morphological characteristics) seeking for principal components through the variance observed in Conopophaga lineata individuals. Addionally t-tests were used to verify if body measurements (wing length, tarsus, nostril, tail and body mass) differ between males and females, if these characteristics differ between small and large fragments, and if fragment size was affecting male and female body measurements differently.

\section{RESULTS}

Plumage was not a totally reliable characteristic in sex determination of $C$. lineata. The molecular technique allowed the exact sexing of individuals otherwise unidentified (three birds) or misidentified as females (five birds), showing that sex determination by plumage coloration had a $10 \%$ error. The use of these two techniques did not show significant differences ( $U=1.38 ; p=0.167)$. Thus, from now on we report only analyses based on molecular sex identification, unless otherwise stated.

We captured a total of 98 C. lineata, 41 females and 57 males, with more individuals captured in small 
$(n=67)$ than in large $(n=31)$ fragments. We captured 11 females and 20 males in the large fragments and 30 females and 37 males in the small fragments, but this ratio was not different from the 1:1 expected proportion. This pattern is the same when each area was tested separately (Tab. I). Also, sex ratio of $C$. lineata did not differ when this proportion was compared between large and small fragments (Mann-Whitney test; $\mathrm{U}=0.7462 ; \mathrm{p}=0.455$ ).

The PCA did not show great difference of morphological characteristics among males and females or due to fragment size. However the principal factors responsible for the variance in Conopophaga lineata were tail, wing and tarsus (Fig. 1, Tab. II). The separate analyses of morphological traits corroborated that male and female $C$. lineata had similar morphological traits. Even though males tended to be larger than females, no difference was observed in the five morphological characteristics analyzed (wing length, tarsus, nostril, tail and body mass) (all p>0.05) (Tab. III). However, analyses of the morphological traits between large and small fragments revealed that the mean size of wing and tarsus were significantly higher in small fragments than in the large ones (Tab. IV). The other three characters analyzed did not differ.

Table I. Sex-ratio (male/female) of Rufous Gnateaters, Conopophaga lineata (Wied, 1831), in small and large forest fragments.

\begin{tabular}{llrrcc}
\hline Size class & Fragment name & $\sigma^{7}$ & \multicolumn{1}{c}{$\chi^{2}$} & $\mathrm{p}$ \\
\hline \multirow{6}{*}{ Small } & João Ribas & 9 & 12 & 0.429 & 0.512 \\
& Mata 36 & 3 & 2 & 0.201 & 0.750 \\
& Mata dos Padres & 5 & 5 & 0.000 & 1.000 \\
& Piedade & 8 & 4 & 1.333 & 0.248 \\
& Primos & 7 & 3 & 1.600 & 0.205 \\
& Mata do Lula & 5 & 4 & 0.738 & 0.813 \\
\hline Total & & 37 & 30 & 0.367 & 0.665 \\
\hline \multirow{4}{*}{ Large } & Jambreiro & 4 & 1 & 1.800 & 0.150 \\
& Mata do Sossego & 4 & 3 & 0.142 & 0.221 \\
& Parque do Brigadeiro & 5 & 4 & 0.055 & 0.890 \\
& Mata Escura & 7 & 3 & 1.600 & 0.205 \\
\hline \multirow{2}{*}{ Total } & & 20 & 11 & 1.335 & 0.248 \\
\hline \multirow{6}{*}{} & & & & &
\end{tabular}

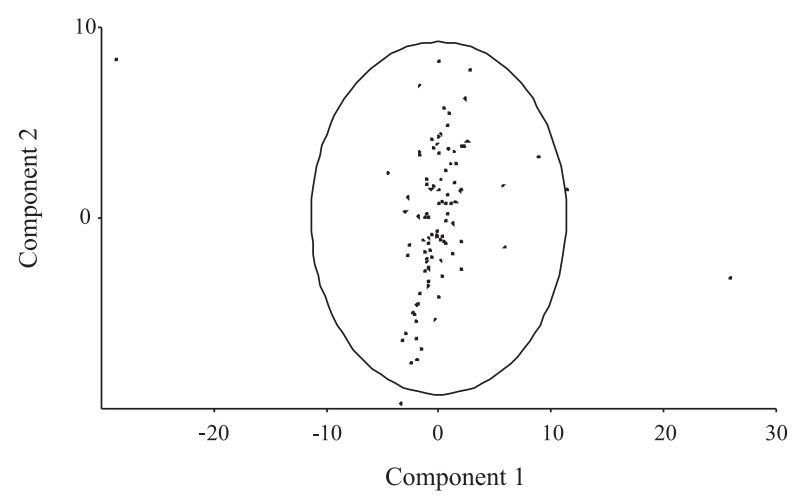

Fig. 1. Principal Component Analysis of morphological characteristics, fragment size and sex of the Rufous Gnateater, Conopophaga lineata (Wied, 1831), Atlantic forest region, Brazil.
Table II. Unrotated Common Factor Matrix of morphological characteristics, fragment size and sex of the Rufous Gnateater, Conopophaga lineata (Wied, 1831), Atlantic forest region, Brazil.

\begin{tabular}{lcc}
\hline Variables & Component 1 & Component 2 \\
\hline Area & -0.006 & -0.005 \\
Sex & 0.009 & 0.021 \\
Weight & -0.046 & -0.078 \\
Wing & -0.140 & -0.052 \\
Tail & -0.147 & -0.823 \\
Tarsus & -0.977 & 0.203 \\
Bill & 0.003 & -0.002 \\
\hline PC & Eigenvalue & Variance \\
\hline 1 & 20.673 & 44.74 \\
2 & 13.625 & 29.49 \\
3 & 8.642 & 18.70 \\
4 & 2.556 & 5.53 \\
5 & 0.290 & 0.62 \\
6 & 0.230 & 0.49 \\
7 & 0.183 & 0.39 \\
\hline
\end{tabular}

Table III. Body measurements of male and female Rufous Gnateaters, Conopophaga lineata (Wied, 1831), compared with t-tests.

\begin{tabular}{llccc}
\hline Variable & \multicolumn{1}{c}{ Sex $(\mathrm{n})$} & Mean \pm SE & $\mathrm{t}$ & $\mathrm{p}$ \\
\hline Body mass $(\mathrm{g})$ & Female $(\mathrm{n}=35)$ & $20.52 \pm 1.82$ & 1.337 & 0.229 \\
& Male $(\mathrm{n}=54)$ & $21.05 \pm 1.49$ & & \\
Wing $(\mathrm{mm})$ & Female $(\mathrm{n}=35)$ & $66.04 \pm 2.85$ & 0.377 & 0.708 \\
& Male $(\mathrm{n}=54)$ & $67.34 \pm 3.83$ & & \\
Tail $(\mathrm{mm})$ & Female $(\mathrm{n}=35)$ & $49.09 \pm 3.48$ & 0.097 & 0.496 \\
& Male $(\mathrm{n}=54)$ & $49.27 \pm 3.14$ & & \\
Tarsus (mm) & Female $(\mathrm{n}=35)$ & $28.53 \pm 1.79$ & 0.409 & 0.137 \\
& Male $(\mathrm{n}=54)$ & $30.07 \pm 5.35$ & & \\
Nostril $(\mathrm{mm})$ & Female $(\mathrm{n}=35)$ & $8.91 \pm 0.50$ & 1.029 & 0.310 \\
& Male $(\mathrm{n}=54)$ & $8.87 \pm 0.47$ & & \\
\hline
\end{tabular}

Table IV. Body measurements of Rufous Gnateaters, Conopophaga lineata (Wied, 1831), in large and small forest fragments compared by t-test. Males and females were considered together.

\begin{tabular}{llccc}
\hline Variable & Fragment Size & Mean \pm SE & $\mathrm{t}$ & $\mathrm{p}$ \\
\hline Body mass $(\mathrm{g})$ & Large $(\mathrm{n}=30)$ & $20.97 \pm 1.96$ & 0.503 & 0.934 \\
& Small $(\mathrm{n}=59)$ & $20.74 \pm 1.44$ & & \\
Wing $(\mathrm{mm})$ & Large $(\mathrm{n}=30)$ & $66.04 \pm 2.42$ & 1.635 & 0.033 \\
& Small $(\mathrm{n}=59)$ & $67.17 \pm 3.47$ & & \\
Tail $(\mathrm{mm})$ & Large $(\mathrm{n}=30)$ & $49.49 \pm 2.60$ & 0.486 & 0.201 \\
& Small $(\mathrm{n}=59)$ & $49.28 \pm 3.29$ & & \\
Tarsus $(\mathrm{mm})$ & Large $(\mathrm{n}=30)$ & $28.35 \pm 2.80$ & 1.537 & $<0.001$ \\
& Small $(\mathrm{n}=59)$ & $28.99 \pm 5.36$ & & \\
Nostril $(\mathrm{mm})$ & Large $(\mathrm{n}=30)$ & $8.81 \pm 0.64$ & 0.002 & 0.579 \\
& Small $(\mathrm{n}=59)$ & $8.97 \pm 0.52$ & & \\
\hline
\end{tabular}

\section{DISCUSSION}

Genetic sexing technique proved to be most adequate for sexing $C$. lineata. Even though most individuals were sexed properly by the color of the post ocular tuft, some male individuals were misidentified as females. These birds might be young males with 
incomplete plumage or, alternatively, individual variations in the color of the post-ocular tuft may occur.

The expectation of biased sex ratio in forest fragments was not supported by our data. Additionally we observed a greater capture rate of $C$. lineata in the smaller fragments (approximately 68\% of the captured individuals), what might reflect higher abundance in the smaller than in the larger fragments. This outcome is probably a consequence of the ability of $C$. lineata to use edge habitats and secondary vegetation (SICK, 1997), and to disperse between forest fragments. Other authors also have showed that this species remains in small fragments, suggesting that $C$. lineata is an Atlantic forest species weakly affected by fragmentation processes (ANCIÃES \& MARINI, 2000).

Forest fragmentation is an important stress for Passeriformes in the Atlantic forest (ANCIÃES \& MARINI, 2000). This stress associated with modification in physical structure of the environmental can lead to changes in morphological characteristics. We observed larger wing and tarsus length in the small fragments, and the difference was not sex related. Although these morphological changes are small, they must be a response to habitat alteration, isolation and/or predation pressure. A larger tarsus gives birds a greater impulse and strength (PougH et al., 1993). Maybe, larger tarsus could allow the individuals to forage on the ground and to escape more effectively from predators.

In general, the wings of forest birds tend to be short and round, especially for understory foraging species such as the Rufous Gnateaters, enabling them to fly around obstacles. The wing length influences beat frequency and consequently the ability and speed to raise flight (Pough et al., 1993). Longer wings, as reported by us for $C$. lineata in the smaller fragments, may represent an adaptation to disperse more efficiently among forest fragments. We must point out that ANCIÃES \& MARINI (2000) also reported higher fluctuating asymmetry of wings of the $C$. lineata in smaller than in larger fragments of the Atlantic rain forest, demonstrating that this species suffers morphological changes due to fragmentation. However, studies on the variation of birds' morphological characteristics related to forest fragmentation are scarce (ANCIÃES \& MARINI, 2000). Specialized species that dependent intensively on forest interior may be affected in different ways by forest fragmentation. Thus, studies that seek to test this pattern must include other forest Neotropical species, in order to understand properly the effects of forest fragmentation.

In conclusion, it was observed in this work that $C$. lineata have been able to survive in both small and large Atlantic forest fragments without altering their sex ratio, but with some morphological changes. This survival is possibly due to its ability to use edge habitat and disperse among forest fragments. However, these outcomes indicate that diverging selection has favored individuals with different morphological characteristics in small and large fragments.

Acknowledgments. This study was developed in the graduate program of Ecologia, Conservação e Manejo da Vida Silvestre - UFMG, with support from USFWS, CNPq and CAPES.
Fieldwork was funded by a grant from CNPq to MÂM and labwork was funded by the Brazilian Long Term Ecological Research grant from $\mathrm{CNPq}$ to FRS. We thank the owners and administrators for giving us permits to study inside their properties, and IBAMA for collecting and banding permits. All samples were collected with the IBAMA permits $011 / 2000$ and $053 / 2001$. This work was also performed according to the special authorization for access to genetic resources in Brazil \# 03/2004 issued by IBAMA/CGEN We are especially grateful to L. Lopes, A. Fernandes and F. Sebaio for help in the field and D. Lacerda and R. Redondo for technical help in the laboratory. C. Miyaki, C. Jacobi, M. Anciães and M. B. Lovato provided criticisms and reviewed previous drafts of the manuscript.

\section{REFERENCES}

AnCiães, M. \& Marini, M. Â. 2000. The effects of fragmentation on fluctuating asymmetry in passerine birds of Brazilian tropical forest. Journal of Applied Ecology 37:1013-1028.

Barbosa, O. \& Marquet, P. A. 2002. Effects of forest fragmentation on the beetle assemblage at the relict forest of Fray Jorge - Chile. Oecologia 32:296-306.

Bierregaard, R. O., JR.; Lovejoy, T. E.; Kapos, V.; Santos, A. A. \& Hutchings, R. W. 1992. The biological dynamics of tropical rainforest fragments: a prospective comparison of fragments and continuous forest. BioScience 42:859-866.

Clutton-Brock, T. H. 1985. Sex ratio variation in birds. Ibis 128:317-329.

Clutton-Brock, T. H.; Albon, S. D. \& Guinness, F. E. 1985. Parental investment and sex differences in juvenile mortality in birds and mammals. Nature 313:131-133.

Cockburn, A.; Legge, S. \& Double, M. C. 2002. Sex ratio in birds and mammals: can the hypotheses be disentangled? In: HARDY, I. C. W. ed. Sex ratio: Concepts and research methods. Cambridge, Cambridge. p.266-286.

Doherty, P. F., JR. \& Grubb, T. C. J. 2002. Survivorship of permanent-resident birds in a fragmented forested landscape. Ecology 83:844-857.

Frankham, R.; Ballou, J. D. \& Briscoe, D. A. 2002. Introduction to conservation genetics. Cambrigde, Cambrigde. $817 \mathrm{p}$.

Griffiths, R; Double, M. C.; OrR, K. \& Dawson, R. 1998. A DNA test to sex most birds. Molecular Ecology 7:1071-1075.

Hair, J. F., JR; Anderson, R. E.; Tatham, R. L. \& Black, W. C. 1995. Multivariate data analysis. New Jersey, Prentice Hall. 730p.

Koivula, M. J. \& Vermeulen, H. J. W. 2005. Highway and forest fragmentation - effects on Carabids Beetles (Coleoptera, Carabidae). Landscape Ecology 20:911-926.

LeAry, R. F. \& AllendorfF, F. W. 1989. Fluctuating asymmetry as an indicator of stress: implications for conservation biology. Trends in Ecology \& Evolution 4:214-217.

Myers, N.; Mittermeier, R. A.; Mittermeier, C. G.; Fonseca, G. A. B \& Kent, J. 2000. Biodiversity hotpots for conservation priorities. Nature 403:853-858.

Paxton, E. H.; Sogge, M. K.; McCarthey, T. D. \& Keim, P. 2002. Nestling sex ratio in the southwestern Willow Flycatcher. Condor 104:877-881

PiANKA, E. R. 1999. Evolutionary ecology. New York, Harper \& Row. 397p.

Pough, F. H.; Heiser, J. B. \& MacFarland, W. N. 1993. A vida dos vertebrados. São Paulo, Atheneu. 823p.

Rolstad, J. 1991. Consequences of forest fragmentation for the dynamics of bird population: conceptual issues and the evidence. Biological Journal of the Linnean Society, Series B, 24:149-163.

SAmbrook, K. J.; Russell, D. W. \& SAmBrooK, J. 2001. Molecular cloning: a laboratory manual. New York, CSHL. 745p.

Santos, F. R.; Bianchi, N. O. \& Pena, S. D. 1996. Worldwide distribution of human Y-chromosome haplotypes. Genome Research 6:601-611.

Seger, J. \& Stubblefield, J. W. 2002. Models of sex ratio evolution. In: Hardy, I. C. W. ed. Sex ratio: Concepts and research methods. Cambridge, Cambridge. p.2-25.

Sheldon, B. C.; Merilä, J.; Lindgren, G. \& Elleggren, H. 1998 Gender and environmental sensitivity in nestling collared flycatchers. Ecology 79:1939-1948. 
SICK, H. 1997. Ornitologia brasileira. Rio de Janeiro, Nova Fronteira. 912p.

SigRIST, T. 2005. Aves Brasil: uma visão artística. São Paulo, Avis Brasilis. 672p.

Soulé, M. E. 1986. Conservation biology: The science of scarcity and diversity. Sunderland, Massachusetts, Sinauer Associates. 584p.
Trivers, R. L. \& Willard, D. A. 1973. Natural selection of parental ability to vary the sex ratio of offspring. Science 179:90-92.

Willis, E. O.; ONIKI, Y. \& SILVA, W. R. 1983. On the behaviour of Rufous Gnateaters (Conopophaga lineata, Formicariidae). Naturalia 8:67-93.

Recebido em maio de 2006. Aceito em setembro de 2007. ISSN 0073-4721

Artigo disponível em: www.scielo.br/isz 